\title{
Russians in the IWMA
}

The Background

\author{
Woodford McClellan
}

In September 2013, Russian President Vladimir Putin advised members of the Federal Assembly, and provincial governors, to study the works of three conservative Russian philosophers. Mirabile dictu, changes in national reading habits and academic curricula got underway overnight. One of the philosophers was the Christian existentialist Nikolai Berdyaev, whose 1919 work on conservative values Putin singled out, but of interest to us here is the 1946 pamphlet Dusha Rossii (The Soul of Russia), in which Berdyaev pronounced Russians "maximalists" by nature.

The Russians - a majority - among the Bolsheviks obviously merited the appellative, as did some predecessors. Oddly enough, one group of direct Bolshevik ancestors did not - the Russian section of the International Working Men's Association (IWMA). In a March 1870 letter declaring allegiance to Karl Marx and the General Council, a group of mostly Russian exiles based in Geneva also proclaimed their fealty to "our teacher," N.G. Chernyshevsky, intellectual leader of the mid-century student radicals. He regarded the peasant commune and the worker cooperative association as foundations on which Russia could leap from feudalism to socialism, bypassing capitalism. In 1890 the first genuine Russian Marxist, Georgi Plekhanov, noted that Chernyshevsky, son of a Russian Orthodox priest, "does not separate out the proletariat from the general mass of suffering and oppressed people." ${ }^{1}$

Marx's socialism, and his theory of proletarian revolution, had nothing in common with Chernyshevsky's peculiarly Russian populism, but the Geneva

* For their kind assistance I am grateful to Deputy Director V.N. Shepelëv, Yuri Tutochkin, and Svetlana Rozental of the Russian State Archive of Social and Political History (RGASPI). Professor Aleksandr Pantsov, and Kathleen Miller, helped in crucial ways with this project. I am indebted to them, and to Professors Stephen Lukashevich and Walter Sablinsky. And I render homage to the memory of the sorely-missed friend who introduced me to the IWMA and Versoix-Genève, Bert Andréas.

1 "N.G. Chernyshevsky," Sotsial-demokrat (Le Démocrate socialiste), London, 189o, Part 1, p. 123. The last six pages of the March 12, 1870 letter, and Anton Trusov's draft bearing the same date, are at RGASPI, f. 21, op. 1, d. 216/3. The Russian section Statute is at ibid., d. 215/1. See below, note 24. The peasant commune was the obshchina, the worker's cooperative the artel.

(C) WOODFORD MCCLELLAN, 2018 | DOI 10.1163/9789004335462_013

This is an open access chapter distributed under the terms of the prevailing CC-BY-NC License. 
group ignored the contrariety. To them, the political insignificance of the homeland's small industrial proletariat - about 460,00o in 1854, excluding miners - was of little consequence. They sympathized with the workers, whose 70hour work-weeks in what the future Menshevik leader Julius Cederbaum called "horrible hygienic conditions" mimicked the situation in the industrialized West, but in their view the peasantry would be the instrument of change. Most from varying degrees of privilege, the Russian section members envisioned no particular role for the proletariat in a revolution in Russia. Convinced that an orgy of blood would, as in France, leave the old regime, or something very like it, in place for a generation or longer in backward Russia, the prospect of uncontrollable peasant violence made them uneasy. ${ }^{2}$

Russian ruling circles shared the anxiety. Stunned by the national humiliation in the Crimea, they feared internal upheaval as the anniversaries of two great peasant rebellions approached, the 1670-1671 Razinshchina and the Pugachyovshchina of 1773-1775. Five hundred fifty peasant "disturbances" struck European Russia in 1855, and rural unrest intensified after promulgation of the Emancipation Edict of 1861, which protected landlord interests. The following two years witnessed about 1,100 serious rabblements (byistva). ${ }^{3}$

The struggle between reformers and reactionaries came to a head in April 1866 when a Chernyshevsky disciple, Dmitry Karakozov, tried to assassinate Alexander II. No revolutionary had ever attempted such an act. Official Russia tilted sharply toward reaction, while at the same time events in Central and Western Europe were moving in the opposite direction. Working-class leaders and leftist intellectuals had sought to resurrect the revolutionary movement of 1848-1849, and in 1864 Karl Marx and others founded the IWMA to champion the cause of labor. Their hopes for progress at home dashed once again, a minuscule band of Russian revolutionaries, joined by some like-minded souls of other nationalities, would make common cause with Western labor.

\section{Blanquism and Anarchism}

At once hoping for and dreading revolution, the dozen or so left-leaning Lac Léman Russians and their allies - a few people of various nationalities - shopped

2 Cederbaum (Russian "Tsederbaum)" wrote as "L. Martov"; see his "Krestianstvo i narodnicheskoe dvizhenie", p. 170, and "Razvitie krupnoi promyshlennosti i rabochee dvizhenie do 1892," pp. 120, 132, both in Istoriia Rossii v XIX veke, vol. vI, St. Petersburg, 1909.

3 Malaya Sovetskaya Entsiklopediya (MSE), vol. 4, Moscow, 1929, col. 334. The MSE and the first edition of the Bolshaya Sovetskaya Entsiklopediya (BSE) remain valuable sources on Bolshevik history. 
the European bazaar of political ideas, finding alongside Marxist socialism several philosophies with ideological high explosives in their arsenals. One, often called socialist revolutionism of a conspiratorial type, had a renowned avatar in Louis-Auguste Blanqui, "inspiration and participant in all Paris uprisings and revolutions between 1830 and $1871 .{ }^{14}$ His exploits, like those of Giuseppe Garibaldi and Mikhail Bakunin, entranced Europe in the second and third quarters of the nineteenth century. Multiple death sentences levied on all three sent nervous shivers through the reading public and convivial discussionists in cafés and pubs and Kneipen. Often misshapen by the time they reached Russia, the tales were nevertheless known, especially in the universities and in the family and social circles of soldiers returned home from pacification and occupation duty in Poland and Hungary.

Already conversant with Blanquism, the Russian section founders learned more when a French medical student, Charles Victor Jaclard, joined their circle after his 1867 marriage to Anna Korvin-Krukovskaya, a Russian feminist, revolutionary socialist, and - with Jaclard - future Communard. She and her sister, the mathematician Sofia Kovalevskaya, were friendly with several members of the Russian section; Anna had come West to study medicine after rejecting Fyodor Dostoevsky's proposal of marriage. Jaclard, a member of one of Blanqui's secret societies, had helped "'Enfermé" escape from the hospital ward of Sainte Pélagie Prison in 1865. Another medical student, Anton Trusov, a Pole from the Russian-occupied national territory, also became a member the Russian section, as did the Swiss Edouard Bongard and the Serb socialist Svetozar Marković. A former Imperial Russian Army officer with the occupation forces in Poland joined them: Konstantin Krupsky had been cashiered on charges that included speaking Polish, dancing the mazurka, and failing to attend Russian Orthodox Church services. The father of Lenin's wife, he sought sanctuary in Switzerland. ${ }^{5}$

Jaclard directed the Geneva group's attention to Blanquism's insistence on social equality and the seizure of power by a small, secretive band of revolutionaries. That appealed to the children of an oppressive society that fostered conspiracies and the grotesque theories that inevitably surround them. They

4 MSE, vol. 1, Moscow, 1928, col. 744.

5 http://ru.rodovid.org/wk/Запись:5862. See the article on Nadezhda Krupskaya (Lenin's wife) in Wikipedia. See also "Krupskii, K.I.," "Trusov, A.D.," and "Hauke-Bosak, Józef," in V.A. Dyakov, Deiateli russkogo i polskogo osvoboditelnogo dvizheniya 1858-1865gg., Moscow, 1967. Count Hauke-Bosak was a friend of several Russian section members, and like Utin, Bongard, Trusov, and Bartenev, a Freemason. Dostoevsky evidently based the character Aglaya Epanchina in The Idiot (published serially in 1868-1869) on Anna Korvin-Krukovskaya. 
were less enthusiastic about Blanqui's rejection of a special role for the intelligentsia in post-revolution society.

Marx and Engels saw history itself as the great strategist of revolution and left it to the avenging proletariat to work out the tactics. Into that puzzling void came Blanquism, which exercised a powerful influence on the Russian revolutionary movement through the Russian section and later through Vera Zasulich, Pyotr Tkachyov, Vera Figner, Sofia Perovskaya, Georgi Plekhanov, I.V. Stalin (the only non-Russian in this group), Nadezhda Krupskaya (Krupsky's daughter), V.I. Lenin - maximalists all. In 1874 Friedrich Engels dismissed Blanqui as "essentially a political revolutionist ... a socialist only through his sympathy with the sufferings of the people," but 1920 Bolshevik party scholarship rejected that judgment: "[D]espite the weakness of Blanqui's philosophical and economic views ... [and] a certain national narrowness of outlook, there is a sound basis for considering him a forerunner of Marx and Lenin."

The Geneva radicals also knew a countryman's collectivist anarchism: A generation earlier, Mikhail Bakunin had turned P.-J. Proudhon's relatively pacific anarchism on its head, pronouncing the "passion for destruction" a "creative passion" and calling for revolution. Utopia would magically materialize. A minister in the Second Republic who knew him personally said, "S'il y avait trois cent Bakounine en France, la France ne serait pas gouvernable."7

Bakunin sought to unleash the "destructive passion" of all the oppressed. Marx wanted to politicize the proletariat, which would make a revolution shaped by proletarian interests alone. The conflict between these approaches to revolution sparked creation of the Russian section of the IWMA.

\section{Nikolai Utin and Land and Liberty}

Notable among the section's founders was Nikolai Isaakovich Utin, son of a Jewish banker who converted to Christianity and had his children baptized in the Russian Orthodox Church, making possible the admission of three sons to St. Petersburg University. In his second year Nikolai won a gold medal in a rigorous academic competition; the "nihilist" Dmitry Pisarev, one of the famous revolutionary "men of the 'sixties," took the silver.

$6 B S E$, 1st ed., Moscow, 1927, vol. 6, col. 487, confirming Blanqui as ideological predecessor of the Bolsheviks. Engels's comment appeared in Der Volkstaat (Leipzig), no. 73, June 26, 1874.

7 Paris, Archives de la Préfecture de Police, B/A 944, pièce 6o. The minister, Ferdinand Flocon, was in civilian life editor of La Réforme, which published articles by Proudhon, Bakunin, Marx, and Engels. 
A close associate of the inspirational leader of leftist students, Nikolai Utin was, a police informer reported, "Chernyshevsky's right hand." ${ }^{8}$ Arrested early in 1862, he was held in prison until his father obtained his release in October. On the surface, he appeared to have learned the proper lessons. He passed his University examinations - but he also joined Zemlya $i$ volya (Land and Liberty), the name of which bespoke populism. Chernyshevsky had inspired the creation of this secret revolutionary society, whose collaborators in exile included Bakunin and the London-based editors of Kolokol (The Bell), Nikolai Ogaryov and Aleksandr Herzen. Banned in Russia, that journal got into the country through smugglers; most of the average press run of 2,500 copies reached St. Petersburg, Moscow, other large cities, and the universities. From 1857 to 1861 Kolokol played a major role in the revolutionary movement. ${ }^{9}$

Still more influential among the young generation was Sovremennik (The Contemporary), a political-literary monthly which Chernyshevsky edited 1859-1861. Published legally in St. Petersburg, its own average press run was 7,100 copies. Herzen excoriated its readership - the young generation that had suddenly lost faith in Kolokol - in an 1866 attack on "superfluous and bilious people" - an allusion to Ivan Turgenev's Diary of a Superfluous Man.

Following the arrest of Chernyshevsky and other Zemlya $i$ volya leaders in the summer of 1862, Nikolai Utin assumed leadership of the central committee. With his future wife Natalia Korsini (Corsini), one of the first women admitted to St. Petersburg University, he directed the clandestine society's post-Sovremennik printing operations. In May 1863, the police closing in, he fled abroad. Korsini soon followed.

\section{Kolokol and the Young Generation}

Utin first went to London to meet with Herzen and Ogaryov, who had badly misinterpreted the Emancipation. Herzen's rhapsodic "Thou hast conquered, O Galilean!" and praise for the "tsar-liberator" disillusioned Zemlya i volya and the progressive young generation, which recognized liberation without sufficient land as a cruel travesty. Hundreds of disorders had erupted in European Russia in the spring and summer of $1861 .{ }^{10}$

8 Utin, N.I.," in Vikipediya: Svobodnaya Entsiklopediya. See also Mikhail Shishkin, Russkaya Shveitsariya, Moscow, 2012, p. $5^{2}$.

9 "Martov" called Zemlya $i$ Volya the "first organization of a socialist type" in Russia; "Krestianstvo ...," p. 164 .

10 Learning that the serfs would be freed in three years, Herzen quoted Emperor Julian the Apostate, who supposedly cried out just before he died of battle wounds, "Nenikekas 
Utin arrived in London with an aggressive agenda. Initial pleasantries disposed of, and his suggestions for new smuggling routes for Kolokol accepted, he proposed that he, representing those who were fighting tsarism in Russia itself, take control of the newspaper and restore its original name, Polyarnaya zvezda (The North Star) to reflect the passing of the guard. He demanded the money a wealthy Russian, P.A. Bakhmetev, had given Herzen and Ogaryov for their work. That understandably angered his hosts, who declared further discussion impossible and refused to publish his article on the revolutionary movement.

The split between the young generation and the London émigrés grew deeper when Kolokol supported the 1863 Polish-Belarusian uprising. Perhaps mindful of its editor's quip that Bakunin "habitually mistakes the third month of pregnancy for the ninth," the modern Russian writer Mikhail Shishkin observes that "[Herzen] overstepped the line where freethinking head collides with patriotic innards."11

A Russian court later sentenced Nikolai Utin to death by firing squad in absentia - no doubt the way he preferred to suffer it. He moved on from London to Switzerland, which generally offered sanctuary to fugitives from the vengeance of royal houses. The Confederation was also home to a few hundred well-to-do Russians who simply found life there agreeable. Comfort-seekers and revolutionaries alike, those fluent in French - Utin included - preferred to live in or near Geneva; others chose Zürich.

At the turn of the year 1864-1865, Utin helped organize a "unity conference" in Geneva, inviting Russian émigrés from around Europe. Still perplexed by the decline of his influence, Herzen accepted. Far from unifying, however, the meeting confirmed the existence of an unbridgeable gulf. Utin persuaded his age cohort to endorse his claim to Kolokol and the Bakhmetev money, and to support his demand that the older generation step aside. Hopes for an accommodation dashed, Herzen wrote to Ogaryov, "Utin is the most hypocritical of our sworn enemies," adding that he was "fed up with the Geneva whelps." Three years later, Fyodor Dostoyevsky, then living in the city, dismissed Utin as one of the "Geneva 'smart-alecks."'12

A leader of the Russian "young emigration" in Switzerland, Aleksandr SernoSolovyovich, helped Utin organize the conference. When a St. Petersburg court convicted him in 1862 of having "dealings with the London propagandists" and

Galilaie!"; Kolokol, 18 February 1858. In general on the reaction in Russia to the emancipation see Tsederbaum -"Martov," “Krestianstvo ...," pp. 162-200.

11 Russkaya Shveitsariya, p. 53.

12 Ibid., pp. 51, 53-55. 
sentenced him to deprivation of property and expulsion from the country, he absconded to Geneva. Also found guilty in the mass trial was his brother, Nikolai, a founder of Zemlya i volya. Condemned to exile in Siberia, he died on the road across the Urals. Tormented by what modern psychology terms "survivor guilt," Aleksandr would commit suicide in $1869 \cdot{ }^{13}$

\section{J.-P. Becker and the Geneva Slavs}

A friend of Karl Marx, the German worker Johann-Philipp Becker, took "Serno" and other refugees under his wing in Geneva, where he had sought refuge when his revolutionary activities incurred the displeasure of the Palatinate authorities in 1849. He became prominent in the local labor movement, brought German and German-Swiss workers and some Slavs into the IWMA, and spearheaded the 1866 Geneva Congress's demand for an eight-hour work day.

Becker introduced Serno-Solovyovich into the IWMA in 1867, the year Marx published Das Kapital. The young Russian expressed a desire to translate the book and soon received a copy, but he was neither trained economist nor sufficiently fluent in German, and nothing came of the project. He had however made a favorable impression on Marx, who exchanged a few letters with him.

Sponsored by Becker, Nikolai Utin became a member of the Carouge - a Geneva suburb - section the following year. Marx did not comment on that step but expressed disapproval when Becker backed two more Russians, Bakunin and his young disciple, Nikolai Zhukovsky, and also Bakunin's wife, Antonia Kwiatkowska, a Pole.

Another Becker protégé, Anton Trusov, had interrupted his medical studies in Moscow to command a guerrilla detachment in the 1863 uprising in Belarus that was quickly crushed by the imperial army. A court-martial sentenced him to death in absentia, but he had already escaped to the West. He went to London and sought out Herzen, only to receive a rebuff. He moved to Paris, found work as a typesetter, and struck up an association with some French socialists. Through the overlapping networks of IWMA members and revolutionaries, his name became known, and Becker invited him to work in Geneva as a typesetter for his - Becker's - friend, Bakunin.

With funds provided by Zoya Obolenskaya, a Russian noblewoman in selfimposed exile in Vevey, the aging anarchist founded the monthly journal Narodnoe Delo - La Cause du Peuple. He hired Trusov and, hoping to cadge

13 The court acquitted Ivan Turgenev in this "Trial of the 32," which dragged out from July 1862 to April 1865 . 
money from the Geneva Russians, made Zhukovsky and Utin co-editors. The Genevans gave no money; Bakunin denied Utin a role in the first issue.

Published on 1 September 1868, the first issue restated familiar anarchist assurances:Violence, destruction, and upheaval would produce a peaceful world free of injustice. The anarchic essence of countless peasant uprisings notwithstanding, that bloody vision had limited appeal in Russia, and Utin sensed that. Backed by several exiles, notably Olga Levashova, Zhukovsky's sister-in-law, he seized control of Bakunin's journal. Trusov joined the venture, as did the Polish émigré Ludwik Czerniecki, printer for Kolokol, which Herzen and Ogaryov had moved to Geneva. ${ }^{14}$

Bakunin did not long lament the loss of Narodnoe Delo. In October he and some Swiss followers announced creation of the International Alliance of Socialist Democracy, which they described as an arm of the IWMA - effectively an "International" within the International. Ignoring the obvious fact that Bakunin's goal was to take over the General Council, J.-P. Becker outraged Marx by urging revision of IWMA statutes to admit the Alliance. The Council refused. Early in 1869 Bakunin declared he would abandon the project, but he dissembled.

\section{Bakunin and Nechaev}

The Alliance lived on, one of two sideshows that sped up formation of the IWMA Russian section; the other was Bakunin's association with Sergei Nechaev. Son of a common laborer father and a mother born a serf, the highly intelligent but psychologically warped Nechaev occupied a lonely position on the fringes of the Russian revolutionary movement, where he tried to mask a monomaniacal hatred of society in general behind an extreme populist façade. Students in Moscow and St. Petersburg, the truly radical and the merely confused, listened, fascinated, as he expounded plans to assassinate the tsar. A master fantasist,

14 Utin discussed the Narodnoe Delo mess in a letter of late May or early June, 1869, to Anton Trusov; see Literaturnoe Nasledstvo (Moscow, 1955) vol. 62, pp. 687-69o. The Neue Zürcher Zeitung noted on March 30, 1870, that "The newspaper 'Kolokol,' founded by Herzen, now appears again under the editorship of a committee of Russian men of the movement." The "committee" consisted of Nechaev and M.K. Elpidin, Bakunin's friend and printer. Olga Levashova and Zoya Obolenskaya were neighbors in Vevey. Olga was a friend of Nikolai and Natalia Utin; Zoya was in Bakunin's camp. After a family quarrel, Zoya Obolenskaya's husband took the couple's children back to Russia. The connivance of the Swiss authorities in the brutal enlèvement disgusted Herzen; see Literaturnoe nasledstvo, (Moscow, 1941) vol. 39-40, pp. 547, 563, and ibid., (Moscow, 1956) vol. 63, p. 139n. 
he spun tales of secret societies, "merciless destruction," a grand settling of accounts with the regime and the rich.

All that brought him to the attention of the Third Section - political police - of His Imperial Majesty's Own Chancellery. In January 1869 he spread the rumor around the capital that he had been arrested, but in fact he went to Moscow and told the young Vera Zasulich, with whom he was only slightly acquainted, that he loved her and wanted her to escape Russia with him. When she declined, Nechaev, using an associate's identity papers, departed alone, going first to Belgium, then to Geneva.

He had never yet been in a police drozhky, but Zasulich told police investigators that she had found a note he threw from one on his way to prison. The strange prevarication won her two years behind bars, and on her release she again fell afoul of the authorities and went back to jail. She established her maximalist credentials in 1878 by shooting and critically wounding the governor of St. Petersburg. In an exchange of letters three years later, she persuaded Karl Marx to reexamine the possibility that Russia could bypass capitalism.

In Switzerland, Nechaev beguiled Bakunin and Ogaryov, men more than thirty years his senior, with tales of escaping from prison and leading a secret underground "five" that planned to assassinate the "tsar-liberator" on the anniversary of the Emancipation decree. He wrote a "Catechism of a Revolutionary" depicting the ideal rebel as a robotic terrorist, interfered in projects to translate the Communist Manifesto and Das Kapital, and threatened to kill anyone who challenged him.

Bakunin impulsively gave his young visitor Card No. 2771 in the non-existent "Russian Section of the World Revolutionary Alliance." And in November 1869 he provided the funds for that visitor to slip back into Russia. On his home territory, Nechaev made good on his threat to do away with any opponent. Now sought for murder as well as political crimes, he returned to Switzerland in January 1870, shortly before Herzen's death, and inveigled Ogaryov into handing over Kolokol and what remained of the Bakhmetev money. As these events unfolded, Dostoevsky was describing him in serially-published chapters of The Demons, in which Nechaev became the terrorist "Pyotr [Peter] Verkhovensky." At the request of the Russian minister in Berne, cantonal police in Geneva and Zürich carried out visites domiciliaires directed at uncovering unlawful activity among the Russian émigrés - specifically, harboring Nechaev, who in fact found no sympathy among the Russian Internationalists and their friends. ${ }^{15}$

15 E.H. Carr, Michael Bakunin. New York, 1961, pp. 390-398. Ruvim Kantor, who had access to Third Section archives, wrote that "None of the prominent revolutionaries of that time 
Briefly the most prominent of those Russians, Aleksandr Serno-Solovyovich contributed articles to L'Egalité, the central section newspaper, and in 1868 he supported a construction workers' strike with propaganda leaflets and speeches. Temporarily preoccupied with caring for a wife with serious eye problems, Nikolai Utin began attending IWMA meetings a little later. He wrote the "Nouvelles Etrangères" section for L'Egalité and eventually became editor. Olga Levashova received a warm welcome when Utin and Becker sponsored her admission to the Geneva women's section. Peter Kropotkin learned in 1874 that the "real soul" of the local labor-IWMA movement was "a most sympathetic Russian lady ... known far and wide amongst the workers as Madame Olga. She was the working force in all the committees."16

\section{The Russian Section}

Speaking to a contingent of several hundred IWMA members gathered at Geneva's Plainpalais Cemetery for the August 1869 funeral for Aleksandr SernoSolovyovich, Utin promised to continue his countryman's work. ${ }^{17}$ "Serno's" suicide on the eve of the IWMA's Basel Congress, and the Bakunin-Nechaev business, weighed heavily on the Geneva émigrés who took part in that Congress - Nikolai and Natalia Utin, Viktor and Yekaterina Bartenev, Olga Levashova, and Anton Trusov. They were part of the majority that neutralized the conservative Proudhonists, until then a sizable anti-General Council bloc. But Bakunin also attended, and he and his followers posed a greater danger, fighting the General Council and Marx on several key questions.

Hermann Jung, a German-Swiss worker who represented Switzerland on the General Council, was elected chairman of the Congress. A close ally of

was hunted as they hunted the mysterious Nechaev"; Vpogone za Nechaevym, Leningrad, 1925, p. 11. The Russian minister in Berne was Nikolai Girs, later foreign minister.

16 Memoirs of a Revolutionist, Mineola, NY, 2010, p. 276; Ante Schrupp, "Die Genfer Frauensektion der Ersten Internationale," http://www.antjeschrupp.de/diegenferfrauensektion, p. 2. Antonia Kwiatkowska was a member of this section. On Utin's work for L'Egalité see his March 24, 1870, letter to Jung at RGASPI, f. 21, op. 1, no further classification. He noted his membership in the Carouge section in the April 7, 1870, report to the General Council of the minority faction at the La-Chaux-de-Fonds congress of the Fédération Romand at ibid., f. 21, op. 1, d. 317 .

17 Utin published an obituary in Narodnoe Delo, no. 7-10, November 1869. Bakunin claimed that "Serno" deplored Utin's revolutionary braggadocio; see my Revolutionary Exiles, London, 1979, p. 84. I regret my error at p. 65, note 24, in writing that B.P. Kozmin exaggerated "Serno's" role in Geneva. He did not. 
Marx, he admonished J.-P. Becker for failing to understand Bakunin's intrigues. Becker apologized, and together the two urged the Utin group to move forward with the creation of a Russian section. Plans that had been in preparation for months came to fruition shortly after the Basel Congress. ${ }^{18}$

Russian and Western scholars having published several monographs on the Russian section, its history is reasonably well known. ${ }^{19}$ Less familiar are recently released materials from the Russian State Archive of Social and Political History. A March 8, 1870, letter from Nikolai Utin to Becker asks for an introduction to Marx, who the aborning Russian section wanted to represent it on the General Council. Utin added that Narodnoe Delo would soon publish a "manifesto to the Slav populations" with news of the IWMA. ${ }^{20}$ Writing to L'Egalité on March 23, 1870, Utin now referred to a "Manifesto to the workers in Slav countries." Its purpose, he wrote, was to induce those workers to "abandon the pernicious ideas of Panslavism and the odious racial rivalry that only profits our common exploiters. ${ }^{21}$

Becker agreed to provide an introduction to Marx. Anton Trusov, secretary of the Geneva group, showed him a draft - noted in the first endnote - of a letter that opened with "Cher et vénérable Citoyen" and went on to praise Marx's "exposé des principes socialistes et [...] critique du système de la Féodalité industrielle." But Trusov overreached in adding, "Your name is rightly venerated by the young Russian student youth, which for the most part comes from the ranks of working people." The first Russian translation of the Communist Manifesto had only just appeared, in Geneva, and could not have reached Russia in significant numbers. Das Kapital was not translated into Russian until 1872; at most a tiny handful of Russians drawn to the recondite subject would have

18 In a March 11, 1870, letter to Jung (RGASPI, f. 21, op. 1, d. 216/2), Utin, Bartenev ("Njetoff"), and Trusov referred to conversations with him and Robert Applegarth, editor of the tradeunion journal The Bee-Hive, at the Congress "et surtout au banquet."

19 V.A. Gorokhov, Russkaya sektsiya Internatsionala (Moscow, 1925); B.P. Kozmin, Russkaya sektsiya Pervogo Internatsionala (Moscow, 1957); B.S. Itenberg, Pervyi Internatsional i revoliutsionnaya Rossiya (Moscow, 1964); and my study mentioned above. Scholarly journals in Russia and the West have published articles on the section.

20 RGASPI, f. 21, op. 1, d. 216/1. Not expecting Becker to be at home, Utin wrote a letter but ended up handing it over directly. In it he noted that "I'm leaving the two envelopes with the addresses you gave to our friend who left for Russia." The friend's identity is not known. The letter cited in note 18 above refers to the Russian section's promise to propagandize the IWMA in the Slav world and attack Bakunin and Nechaev. Utin asked that everything in Russian be turned over to him. The letter proves Becker's involvement in the smuggling of communications into Russia.

RGASPI, f. 21, op. 1, d. 216/4. The final page or pages are missing. 
had access to the German original. ${ }^{22}$ Only one Russian revolutionary in Switzerland and perhaps all Europe could legitimately claim working-class origin: Sergei Nechaev.

Trusov's draft had noted in passing that the nascent Russian section had "absolutely nothing in common" with Bakunin. The letter that actually went to Marx reflected both Becker's editing and some suggestions from Hermann Jung. Marx and Jung having chastised him for coddling Bakunin, Becker was anxious to redeem himself. As the patron of people ready to establish an anti-Bakuninist IWMA section, an ideal peace offering was at his disposal. He advised the Geneva group to spell out in detail its differences with Europe's leading anarchist. ${ }^{23}$

They took the advice. As we have seen, their letter to Marx proclaiming solidarity with him and the General Council simultaneously acknowledged allegiance to Chernyshevsky. The rest embodied an attack on the individuals they now, agreeing with Marx, considered the biggest threat to the IWMA. Bakunin and Nechaev, they wrote, believed that the "only true type of revolutionary is the Russian highway bandit," and in that guise they were trying to take over the Russian section before it officially came into existence, and to reassume control of Narodnoe Delo. One of their agents in the effort was a young Russian recently arrived in Switzerland, Vladimir Serebrennikov, whom the letter described as an " intelligent lad, but corrupt to the nth degree." Proclaiming his support for the Geneva circle's goals, he revealed his true character with a threat on the life of an unnamed woman who had told Utin and Trusov of "rapports intimes" with Nechaev - who was now back in Western Europe. ${ }^{24}$

The Geneva group praised Marx for founding the International and for his unceasing efforts to unmask "false Russian patriotism, the false subtleties of our Demosthenes who prophesize the glorious predestination [sic] of these Slav peoples who until today have only the predestination of being crushed by Tatar tsarism." That pleased one of Europe's best-known Russophobes, who agreed to act for the group on the General Council. He saw the humor in the

22 Plekhanov, "N.G. Chernyshevsky," Part 1, pp. 122f.

23 Utin's 1 April 1870, letter to him reveals that Jung helped edit the correspondence and led Utin to apologize for addressing Marx as "venerable." Becker had informed Utin that Marx was "only $5^{\circ}$ "; he turned $5^{2}$ on May 5,1870 . See RGASPI, f. 21, op. 1 ; the typewritten letter is not further indexed.

24 The last of the six pages of this letter I have seen (see note 1) ends with "Salut et fraternité" and the signatures. The Russian section's founders recognized Serebrennikov as an accomplice of Nechaev and Bakunin in March 1870, three months before the date I gave in Revolutionary Exiles, p. 98. 
situation and wrote to Engels, "Drôle de position für mich, als Repräsentant der Jeune Russie zu funktionieren." 25

\section{Conclusion}

Marx's new allies, a very small company of Russian émigrés and their friends of various nationalities, pledged to propagate his ideas in a country with proportionately the smallest proletariat in the industrialized world. And they promised to send that message to other Slav lands including enclaves in the Austro-Hungarian and Ottoman empires, where the concept of "proletariat" was scarcely known. The Russian section made some progress in this area, establishing contact with revolutionary circles inside Russia and arranging to smuggle in the Communist Manifesto and others of Marx's works, and IWMA publications. Not until the 1880s, however, did Marxist socialism take root in Russia, and for decades after that it barely registered elsewhere in Slavdom. ${ }^{26}$

The Russian section's service to Marx and the IWMA consisted of joining the struggle against anarchism and proving the existence of movement in Russia that could stand - however awkwardly - with Western revolutionaries to combat injustice. Nikolai Utin, the section's dominant figure, entered the battle against the anarchists in the wake of the Nechaev affair and launched a protracted diatribe against Bakunin, attacking in L'Egalité and Narodnoe Delo; correspondence with Marx, Becker, and Jung; presentations to the IWMA 1871 Conference in London and the 1872 Congress - the last - in The Hague; and an 1873 brochure.

Utin had signaled his intentions in a March 24, 1870, letter to Jung explaining the Russian section's public break with Bakunin and his "acolytes." Their acts and conduct, he wrote, were "more harmful to the great cause of the Liberation of the Proletariat than all the stupid attacks of our official enemies." There was more in this vein, then the crux of the dispute: Bakunin's friends, Utin told Jung, "want at all costs to force L'Egalité to preach political abstention for the Internationalists." 27

25 Karl Marx and Friedrich Engels, Werke (Berlin, 1965) vol. 32, p. 466.

26 In "Svyazi Russkoi sektsii Pervogo Internatsionala s revoliutsionnym dvizheniem v Rossii," his dissertation for Kazan State University (Kazan, 1990), V.A. Shagalov, who had access to Third Section archives, wrote that the Russian section of the IwMA had extensive contacts with revolutionary groups in Russia, and through them disseminated the works of Marx and Engels, J.-P. Becker, and others. Having seen only the dissertation abstract, I am unable to evaluate this assertion, which diverges from previous scholarship. 
Marx and the General Council prevailed over the anarchists, whom the Hague Congress expelled from the IWMA. The expulsion and the relocation of the Council to New York, however, spelled the demise of the first modern working-class political organization. Nikolai Utin contributed to the defeat of Bakunin and his followers, but that did not make him a Marxist. He and other section members were marxisant; none were maximalists in the Berdyaev sense. Utin and Yelizaveta Tomanovskaya, a member of the section and the heroic "Mme Dmitrieff" of the Paris Commune, became Marx's personal friends but were only happenstance, and temporary, political allies. They, and Natalia Utina née Korsini, Viktor and Yekaterina Bartenev, Olga Levashova, the Communards Victor and Anna (née Korvin-Krukovskaya) Jaclard, Anton Trusov, Edouard Bongard, Svetozar Marković, and Konstantin Krupsky, played their brief roles on the world stage well, then faded into the dim historical background. 